\title{
Penampilan Vegetatif Tiga Genotipe Kedelai Berbiji Besar Pada Kondisi Stres Genangan
}

\section{Vegetative Appearance of Three Genotypes of Large-Seeded Soybean in Puddle Stress Conditions}

\author{
Kisman*, A. Farid Hemon, Sumarjan, Suprayanti Martia Dewi \\ Jurusan Budidaya Pertanian, Fakultas Pertanian, Universitas Mataram \\ *Corresponding Author Email: kisman@unram.ac.id
}

Manuscript received: 08-12-2020. Accepted: 05-10-2021

\begin{abstract}
ABSTRAK
Penelitian ini bertujuan untuk mengetahui penampilan karakter vegetatif tiga genotipe kedelai berbiji besar pada kondisi stres genangan. Metode yang digunakan adalah Metode Eksperimental menggunakan ember plastik sebagai unit percobaan yang diatur tata letaknya menggunakan Rancangan Petak Terpisah. Petak utama adalah faktor stres genangan (S) terdiri atas kondisi normal (S0) dan stres genangan (S1), dan anak petak adalah faktor genotipe (G) terdiri atas G1 (KH1), G2 (Argomulyo), dan G2 (Grobogan). Setiap genotipe diulang empat kali. Peubah yang diamati adalah tinggi tanaman, jumlah daun, luas daun, jumlah cabang produktif, bobot daun spesifik, rasio berat kering akar/tajuk. Hasil penelitian menunjukkan bahwa terdapat perbedaan penampilan karakter vegetatif tiga genotipe kedelai biji besar pada kondisi stres genangan terutama pada sifat tinggi tanaman, luas daun, berat kering akar, dan berat kering tajuk. Pada kondisi stres genangan, KH1 menunjukkan tinggi tanaman, berat kering akar, dan berat kering tajuk yang paling tinggi. Argomulyo menunjukkan luas daun yang paling tinggi, sedangkan Grobogan justru tidak menunjukkan karakter dominan pada kondisi stres genangan.
\end{abstract}

Kata kunci: kedelai, genotipe, stres, genangan, vegetatif

\begin{abstract}
This study aims to determine the vegetative appearance of three genotypes of large-seeded soybean under puddle stress. The Experimental method was used and the plastic buckets as the experimental units were arranged using a Split Plot Design. The main plot was the stress factor (S) consisting of normal conditions (S0) and puddle stress (S1), and the subplot was the genotype factor (G) consisting of G1 (KH1), G2 (Argomulyo), and G2 (Grobogan). Each genotype was repeated four times. The observed variables were plant height, number of leaves, leaf area, number of productive branches, specific leaf weight, root/shoot dry weight ratio. The results showed that there were significantly differences in the appearance of the vegetative characters of the three genotypes of large seeded soybean under puddle stress conditions, especially on plant height, leaf area, plant dry weight, and shoot dry weight. Under puddle stress conditions, KH1 showed the highest of the plant height, root dry weight, and shoot dry weight. Argomulyo showed the highest of the leaf area, while Grobogan did not show as a tolerant variety under puddle stress conditions.
\end{abstract}

Keyword: soybean, genotype, stress, puddle, vegetative 


\section{PENDAHULUAN}

Kedelai (Glycine max (L) Merrill) merupakan salah satu tanaman palawija yang cukup strategis karena menjadi penghasil bahan baku utama produk pangan olahan seperti tempe, tahu, tauco, kecap, susu dan lain-lain yang dikenal sebagai sumber protein nabati yang tergolong mudah diperoleh, murah dan terjangkau oleh sebagian besar masyarakat Indonesia. Kedelai dapat diolah menjadi berbagai produk pangan seperti tempe, tahu, tauco, kecap, susu dan lain-lain.

Pelaku usaha pembuatan tempe dan tahu menggunakan kedelai berbiji besar sebagai bahan baku utamanya, sehingga petani kedelai cenderung menanam kedelai berbiji besar. Beberapa varietas kedelai beirbiji besar antara lain: Argomulyo, Burangrang, Anjasmoro, Grobogan, Panderman yang memiliki ukuran biji >14 g per 100 biji [1].

Produksi kedelai nasional saat ini masih baru bisa memenuhi 1/3 kebutuhan nasional. Oleh karena itu diperlukan upaya peningkatan produksi [2]. Peningkatan produksi kedelai nasional terkendala oleh keterbatasan lahan yang sesuai untuk pertumbuhan dan perkembangan tanaman kedelai. Menurut Hapsari dan Adi [3] sekitar 60\% tanaman kedelai di Indonesia ditanam di lahan sawah. Akan tetapi tanaman kedelai yang ditanam di lahan sawah sering mengalami cekaman genangan karena intensitas curah hujan yang tinggi dan pola hujan yang tidak menentu sebagai dampak dari perubahan iklim. Genangan menyebabkan penuaan dini sehingga daun klorosis, nekrosis, dan gugur serta pertumbuhan tanaman terhambat, yang pada akhirnya menurunkan hasil. Besarnya penurunan hasil bergantung pada varietas kedelai yang ditanam, fase pertumbuhan tanaman, lamanya tergenang, tekstur tanah, dan kehadiran penyakit. Menurut Efendi dan Suwarti [4], subsektor tanaman pangan paling terpengaruh dengan perubahan iklim. Hal ini karena tanaman pangan umumnya merupakan tanaman semusim yang relatif sensitif terhadap cekaman, terutama kelebihan dan kekurangan air.

Kedelai yang ditanam di sawah setelah padi pada akhir musim hujan (April-Juni) masih mendapatkan curah hujan yang cukup untuk pertumbuhan awal, namun perubahan iklim dimana terjadi curah hujan tinggi meningkatkan resiko tergenangnya pertanaman kedelai pada fase vegetatif, sehingga dapat mengakibatkan penurunan produksi. Hapsari dan Adi (2010) [3], umumnya kehilangan hasil akibat cekaman genangan pada fase vegetatif lebih kecil dibandingkan pada fase reproduktif, yaitu $17-43 \%$ pada fase vegetatif dan $50-56 \%$ pada fase reproduktif.

Genangan pada pertanaman kedelai yang cukup lama merupakan salah satu cekaman abiotik yang harus diperhatikan saat ini karena dapat menyebabkan peningkatan $\mathrm{H} 2 \mathrm{O}$ dan penurunan kadar $\mathrm{O} 2$ pada bagian tanaman yang terendam, khususnya pada akar. Menurut Fatimah dan Saputra [5], cekaman genangan air (waterlogging) dapat menyebabkan penuaan dini sehingga daun klorosis, nekrosis, dan gugur serta pertumbuhan tanaman terhambat yang pada akhirnya menurunkan hasil (produktivitas). Besarnya penurunan hasil ini juga tergantung pada varietas kedelai yang ditanam, fase pertumbuhan tanaman, lamanya tergenang, tekstur tanah, dan adanya penyakit.

Cekaman genangan memiliki dampak terhadap organ-organ vegetatif tanaman, seperti terjadinya penurunan luas daun dan hipertrofi batang serta meningkatnya pertumbuhan 
diameter batang, juga bisa menyebabkan pembusukan akar, menghambat pertumbuhan cabang akar dan pertumbuhan akar yang sudah ada [6] dalam [7]. Oleh karena itu diperlukan genotipe tanaman yang adaptif dan toleran terhadap cekaman genangan.

Program perakitan varietas kedelai toleran genangan berpeluang dilakukan jika tersedia sumber gen dan metode skrining yang sederhana, mudah serta cepat. Karakter morfologi, fisiologi, dan anatomi yang dapat secara cepat mendeteksi indikator toleransi kedelai terhadap genangan antara lain adalah perkecambahan, tinggi tanaman, perubahan warna daun menjadi kuning, kehadiran akar adventif, bobot kering akar, penutupan stomata, dan kadar $\mathrm{N}$ total [3].

Respon atau penampilan morfologi, anatomi dan fisiologi tanaman terhadap cekaman genangan berbeda-beda tergantung genotipe, fase pertumbuhan dan perkembangan tanaman. Beberapa penelitian terkait cekaman genangan telah dilakukan pada beberapa jenis tanaman seperti pada tanaman jagung [8]; [9], pada tanaman cabai [10], melaporkan bahwa ada beberapa genotipe tanaman jagung yang dapat bertahan terhadap cekaman genangan melalui mekanisme morfofisiologis dengan membentuk jaringan aerenchim maupun akar adventif. Selain itu dilaporkan bahwa akibat cekaman genangan terjadi penghambatan dan penurunan daya tumbuh bahkan kematian tanaman jagung karena suplai oksigen melalui akar yang mempengaruhi metabolisme tanaman. Fatimah dan Saputro [5] juga melaporkan bahwa rasio akar varietas Grobogan lebih tinggi dibanding rasio tajuk pada kondisi cekaman genangan.

Berdasarkan uraian diatas maka telah dilakukan penelitian yang bertujuan untuk mengetahui penampilan vegetatif tiga genotipe kedelai berbiji besar pada kondisi stres genangan.

\section{METODE}

Metode yang digunakan dalam penelitian ini adalah metode eksperimental dengan percobaan di rumah kaca dimana penanaman dilakukan menggunakan polybag dan pot plastik.

\section{Bahan}

Materi genetik yang digunakan adalah Galur Harapan kedelai biji coklat biji besar (KH1), Argomulyo, Grobogan. Selain itu bahan yang digunakan adalah air, tanah sawah, pot plastik, bambu, pupuk kandang, pupuk NPK Phonska, insektisida Mipsin, Furadan 3G, Dhitane M 45 dan Movento

\section{Rancangan Percobaan}

Rancangan percobaan yang digunakan adalah Rancangan Acak Lengkap dengan dua faktor percobaan dan masing-masing perlakuan diulang empat kali. Faktor pertama adalah cekaman genangan (S) yaitu: S0 = kontrol (tanpa cekaman), S1 = cekaman genangan (jenuh air). Faktor kedua adalah genotipe $(\mathrm{G})$ yang terdiri atas: G1 = GH KH1, G2 = Argomulyo, G3 $=$ Grobogan.

\section{Pelaksanaan Percobaan}

Penyiapan media tanam menggunakan tanah sawah yang terlebih dahulu diayak dan dibersihkan dari kotoran dan batu kemudian dicampur pupuk kandang dengan perbandingan 2:1 dan ditimbang seberat $7 \mathrm{~kg}$ dan dimasukkan ke pot. 
Benih kedelai yang digunakan adalah benih kedelai GH KH1, Argomulyo, dan Grobogan. Sebelum ditanam benih kedelai yang tersimpan pada tempat yang bersuhu rendah (dalam kulkas) dikeluarkan kemudian dikeringanginkan. Sebelum ditanam benih kedelai diperlakukan dengan seed streatment untuk menghindari jamur atau hama dan penyakit yang terbawa benih.

Penanaman dilakukan dengan cara benih kedelai dimasukkan ke dalam lubang tanam yang telah dibuat sedalam 2-3 cm dan ditanam 3 biji benih serta ditaburkan Furadan 3G sekitar $0,03 \mathrm{~g}$ per pot. Setelah itu ditutup kembali menggunakan tanah tipis-tipis. Setiap pot diatur letaknya dengan jarak $25 \mathrm{~cm}$ x $25 \mathrm{~cm}$.

Penyulaman dilakukan pada saat tanaman berumur satu minggu setelah tanam. Benih yang tidak tumbuh, mati atau rusak segera disulam menggunakan benih baru dari genotipe yang sama. Selanjutnya dibiarkan dua tanaman sehat tiap pot, satu tanaman untuk pengamatan destruktif untuk pengamatan fisiologi dan anatomi, satu tanaman untuk pengamatan hasil dan komponen hasil.

Pemupukan dilakukan sebanyak dua kali dalam satu kali tanam. Pemupukan pertama dilakukan sebelum tanam dan pemupukan kedua dilakukan saat tanaman berumur 3 MST (minggu setelah tanam). Pupuk yang digunakan adalah pupuk NPK Phonska dengan dosis 50 $\mathrm{kg} / \mathrm{ha}$, sehingga kebutuhan per tanaman $0,3 \mathrm{~g} /$ tanaman dengan cara dibenamkan di dalam tanah pada pot.

Penyiangan dilakukan sekali seminggu pada saat tanaman berumur 1-6 MST (minggu setelah tanam) atau jika ada gulma. Pada saat penyiangan dilakukan penggemburan tanah di sekitar perakaran tanaman untuk menjaga aerasi daerah perakaran.

Pengendalian hama dan penyakit dilakukan terhadap hama seperti penghisap daun, ulat penggerek, perusak daun, wereng daun, ulat grayak dan lalat bibit menggunakan insektisida Mipsin dengan konsentrasi $43 \mathrm{ml}$ dicampur dengan $1600 \mathrm{ml}$ air. Pengendalian penyakit seperti karat daun, layu jamur, bercak daun bakteri, busuk batang, dan antraknosa, dilakukan dengan menyemprotkan fungisida Dithane M 45 dengan dosis 2 g/liter air.

Pemanenan kedelai dilakukan apabila sebagian besar daun sudah menguning, gugur, buah mulai berubah warna menjadi kuning kecoklatan atau polong sudah kelihatan tua, batang berwarna kuning agak coklat. Panen dilakukan dengan cara mencabut batang tanaman kedelai bersama akar secara hati- hati, dibersihkan akar tanaman dari tanah, untuk dilakukan pengamatan.

\section{Variabel pengamatan}

Pengamatan dilakukan terhadap karakter vegetatif pada semua genotipe kedelai yang diuji yang meliputi: tinggi tanaman, diameter batang utama, jumlah buku subur, jumlah dan luas daun trifoliat, bobot daun spesifik, berat brangkasan akar, tajuk, dan rasio berat kering akar/tajuk. Pengamatan dilakukan pada umur tanaman 3, 4, 5, 6 MST menggunakan sampel tanaman destruktif. 


\section{Analisis Data}

Data hasil pengamatan dianalisa menggunakan analisis ragam pada taraf nyata $5 \%$. Apabila terdapat beda nyata dilakukan uji lanjut menggunakan uji lanjut DMRT (Duncan Multiple Range Test) pada taraf 5\% menggunakan program CoStat for Window.

\section{HASIL DAN PEMBAHASAN}

Sebagaimana yang ditunjukkan pada Tabel 1, hasil analisis ragam terhadap sifat vegetatif yang diamati pada umur 6 MST menunjukkan bahwa faktor tunggal genangan secara nyata berpengaruh terhadap penampilan sifat tinggi tanaman, diameter batang utama, luas daun trifolaiat, berat kering akar, berat kering tajuk, dan rasio berat akar/tajuk. Faktor genotipe hanya memberikan dampak yang berbeda nyata pada penampilan sifat luas daun saja. Sedangkan iInteraksi kedua faktor genotipe dan genangan tidak memberikan dampak yang nyata terhadap penampilan sifat vegetatif ketiga genotipe kedelai berbiji besar pada kondisi cekaman genangan.

Tabel 1. Ringkasan hasil sidik ragam penampilan karakter vegetatif tiga kedelai biji besar pada kondisi stres genangan

\begin{tabular}{|c|c|c|c|c|c|c|c|c|c|c|c|}
\hline \multirow{2}{*}{$\begin{array}{c}\text { Sumber } \\
\text { Keragaman }\end{array}$} & \multicolumn{11}{|c|}{ Karakter vegetatif } \\
\hline & TT & $\overline{D B}$ & JB & JD & $\mathrm{LD}$ & BKD & BDS & $\begin{array}{c}\text { BK } \\
\text { A }\end{array}$ & BKT & $\mathrm{R}(\mathrm{A} / \mathrm{T})$ & $\mathrm{BB}$ \\
\hline Genangan & $\mathrm{s}$ & ss & ns & ns & $\mathrm{s}$ & ns & ns & ss & ss & ss & ns \\
\hline Genotipe & $\mathrm{ns}$ & $\mathrm{ns}$ & $\mathrm{ns}$ & $\mathrm{s}$ & $\mathrm{ns}$ & $\mathrm{ns}$ & $\mathrm{ns}$ & $\mathrm{ns}$ & $\mathrm{ns}$ & $\mathrm{ns}$ & $\mathrm{ns}$ \\
\hline $\begin{array}{c}\text { Genangan*Ge } \\
\text { notipe }\end{array}$ & ns & $\mathrm{ns}$ & ns & $\mathrm{ns}$ & $\mathrm{ns}$ & $\mathrm{ns}$ & ns & $\mathrm{ns}$ & ns & ns & ns \\
\hline
\end{tabular}

Keterangan:

$\mathrm{s}=$ berbeda nyata $5 \%, \mathrm{ss}=$ sangat berbeda nyata $1 \%, \mathrm{~ns}=$ tidak berbeda nyata

$\mathrm{TT}=$ tinggi tanaman $(\mathrm{cm}), \mathrm{DB}=$ diameter batang, $\mathrm{JB}=$ jumlah buku subur, $\mathrm{JD}=$ jumlah daun trifoliat, $\mathrm{LD}=$ luas daun trifoliat, $\mathrm{BKD}=$ berat kering daun trifoliat, $\mathrm{BDS}=$ bobot daun spesifik, $\mathrm{BKA}=$ berat kering akar, $\mathrm{BKT}=$ berat kering tajuk, $\mathrm{R}(\mathrm{A} / \mathrm{T})=$ rasio akar tajuk, $\mathrm{BB}=$ berat brangkasan

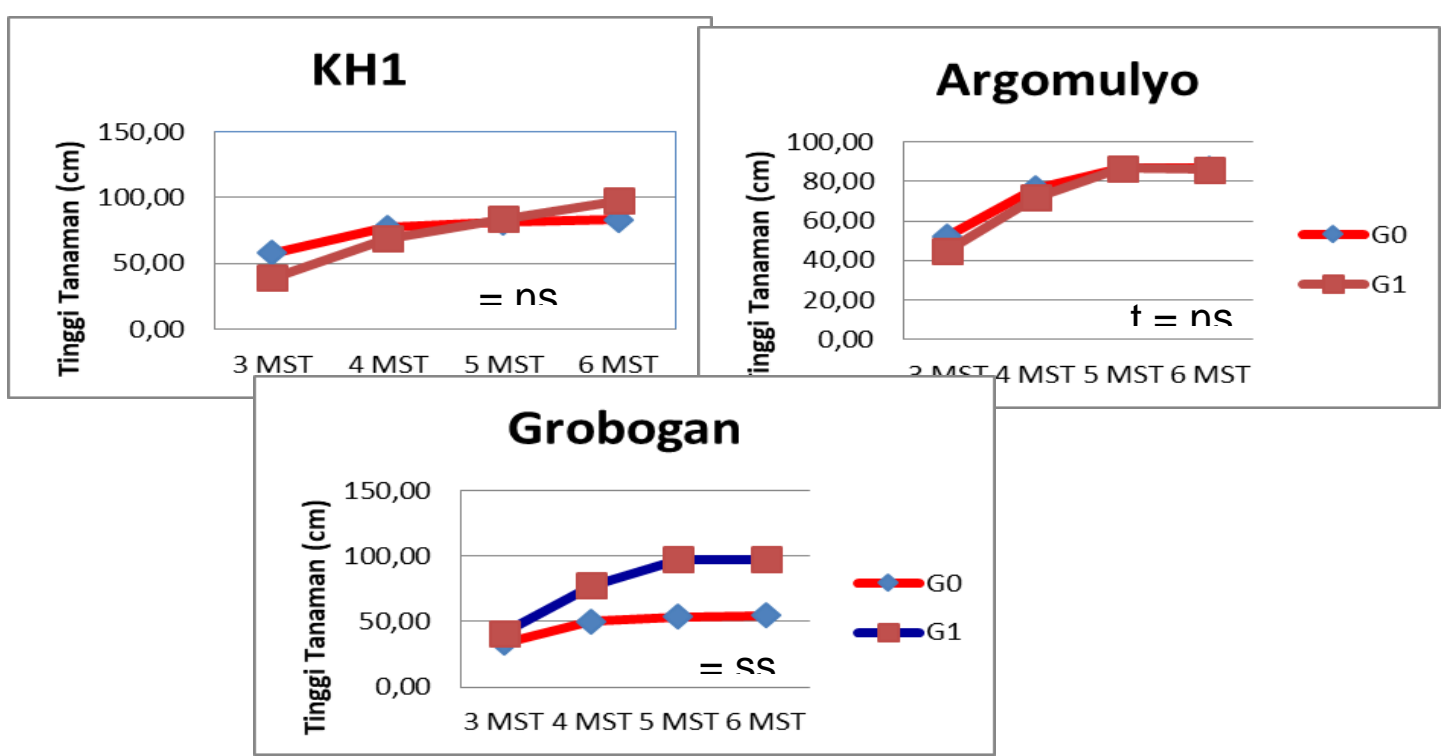

Gambar 1. Penampilan tinggi tanaman KH1, Argomulyo, dan Grobogan pada kondisi cekaman genangan 
Penampilan sifat tinggi tanaman yang diamati pada umur 3 MST sampai dengan 6 MST dapat dilihat pada Gambar 1. Pada Gambar 1 terlihat bahwa genotipe Grobogan menunjukkan perbedaan pertumbuhan tinggi tanaman yang sangat signifikan dibandingkan dengan KH1 dan Argomulyo, dimana pada kondisi cekaman genangan pertumbuhan tinggi tanaman sejak umur 4 - 6 MST jauh lebih tinggi dibanding kondisi normal. KH1 menunjukkan pola pertumbuhan yang berbeda dengan genotipe yang lain dimana pada pengamatan umur 3 MST dan 4 MST tinggi tanaman pada kondisi genangan lebih rendah dibanding pada kondisi normal namun pada umur 6 MST lebih tinggi tanamannya pada kondisi cekaman genangan. KH1 menunjukkan rata-rata tinggi tanaman lebih tinggi dibanding Argomulyo dan Grobogan. Menurut Hapsari dan Adie [3], tinggi tanaman dapat menjadi indikator seleksi pada percobaan di rumah kaca dan di lapang. Hasil penelitiannya pada tahun 1997 menunjukkan bahwa galur kedelai yang toleran mampu mempertahankan tinggi tanaman saat berbunga. Hal ini sejalan dengan yang dilaporkan VanToai et al. [11] dalam Hapsari dan Adie [3] bahwa pada kondisi tergenang, kedelai yang toleran genangan memiliki tinggi tanaman $29 \%$ lebih tinggi daripada yang peka.
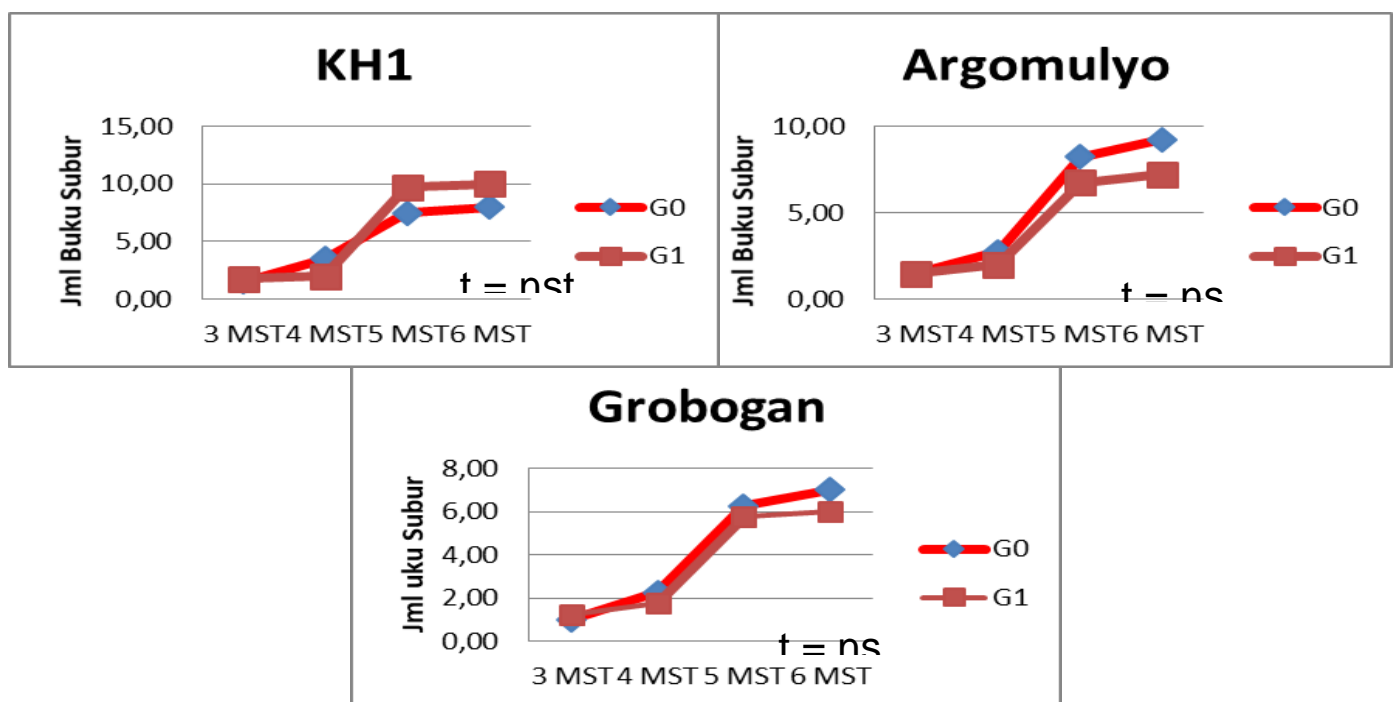

Gambar 2. Penampilan sifat jumlah buku subur KH1, Argomulyo, dan Grobogan pada kondisi cekaman genangan

Pada Gambar 2, ketiga genotipe KH1, Argomulyo, Grobogan menunjukkan pola pertumbuhan sifat jumlah buku subur yang sama pada kondisi kontrol dan cekaman genangan. KH1 menunjukkan jumlah buku subur pada umur 5 MST dan 6 MST lebih banyak pada kondisi genangan dibanding pada kondisi normal, dan ini berbeda dengan Argomulyo dan Grobogan yang menunjukkan jumlah buku subur yang lebih sedikit pada kondisi cekaman genangan dibanding kondisi normal sejak pengamatan umur 4 MST sampai 6 MST. Rata-rata jumlah buku subur pada KH1 juga menunjukkan lebih tinggi dibanding genotipe yang lain, sedangkan yang paling sedikit adalah Grobogan.

Pada Gambar 3 terlihat bahwa diameter batang KH1, Argomulyo dan Grobogan lebih tinggi pada pada kondisi genangan dibandingkan pada kondisi normal terutama pada umur 5 MST dan 6 MST. 
Pada Gambar 4 tampak bahwa rata-rata jumlah daun trifoliat KH1 lebih tinggi dibanding Argomulyo dan Grobogan dan yang paling sedikit ditunjukkan oleh Grobogan. Pola pertumbuhan jumlah daun trifoliat yang sama ditunjukkan oleh ketiga genotipe tersebut dimana pada kondisi cekaman genangan jumlah daun trifoliat lebih sedikit dibanding pada kondisi normal.

Pada Gambar 5 tampak bahwa luas daun trifoliat dari ketiga genotipe yang diuji menunjukkan lebih tinggi pada kondisi cekaman genangan dibanding pada kondisi normal. KH1 menunjukkan rata-rata luas daun trifoliat paling tinggi dan yang paling rendah adalah Grobogan.

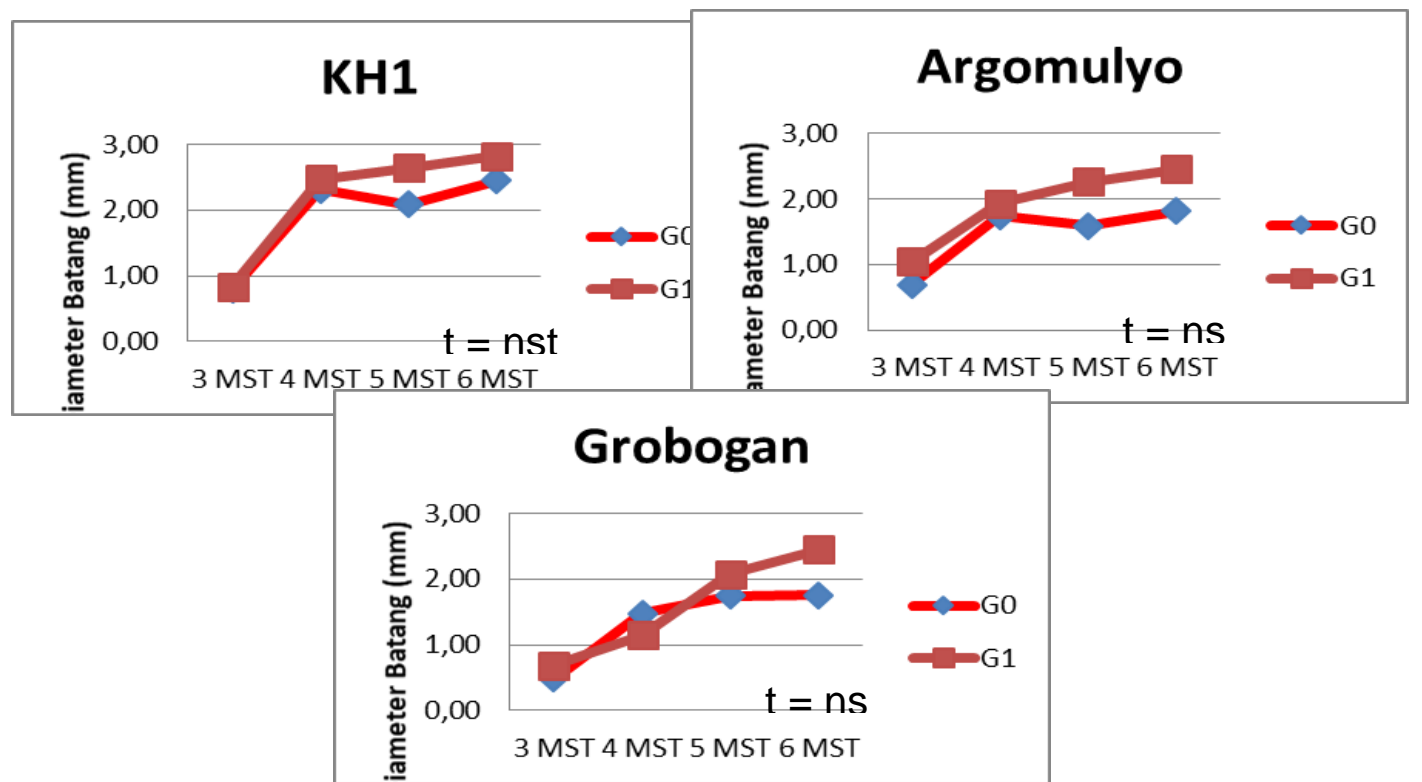

Gambar 3. Penampilan sifat diameter batang KH1, Argomulyo, dan Grobogan pada kondisi cekaman genangan

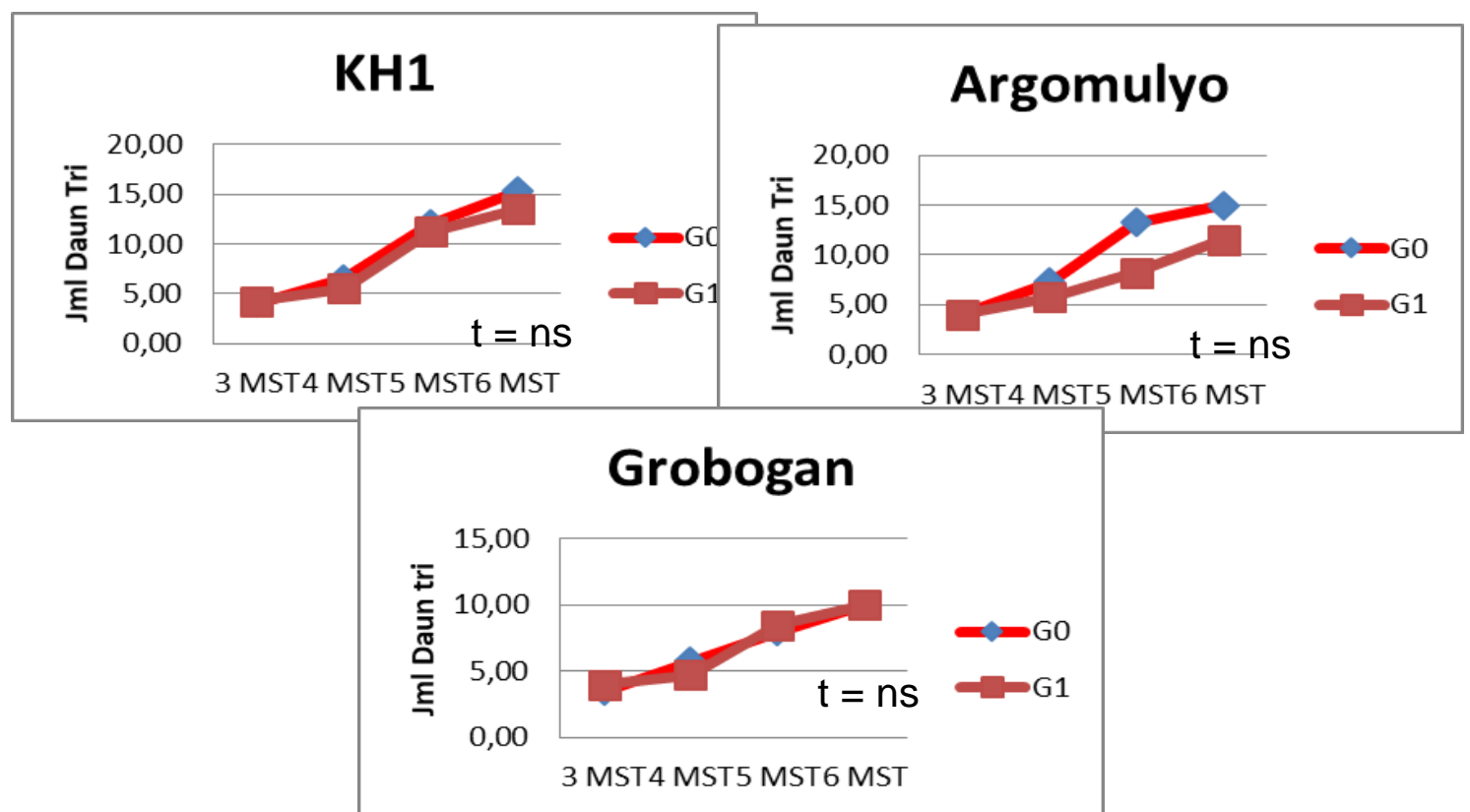

Gambar 4. Penampilan sifat jumlah daun trifoliat KH1, Argomulyo, dan Grobogan pada kondisi cekaman genangan 


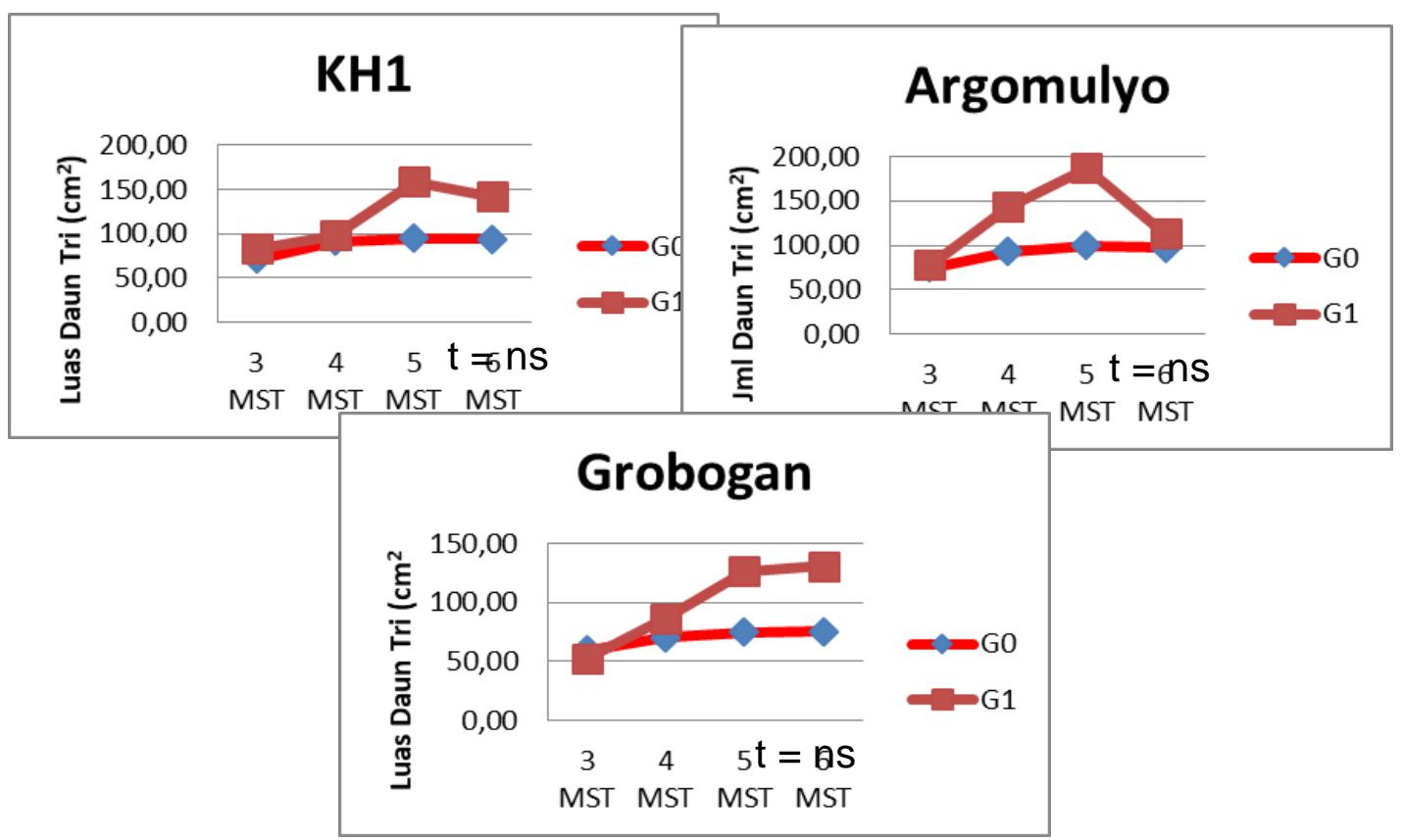

Gambar 5. Penampilan sifat luas daun trifoliat KH1, Argomulyo, dan Grobogan pada kondisi cekaman genangan
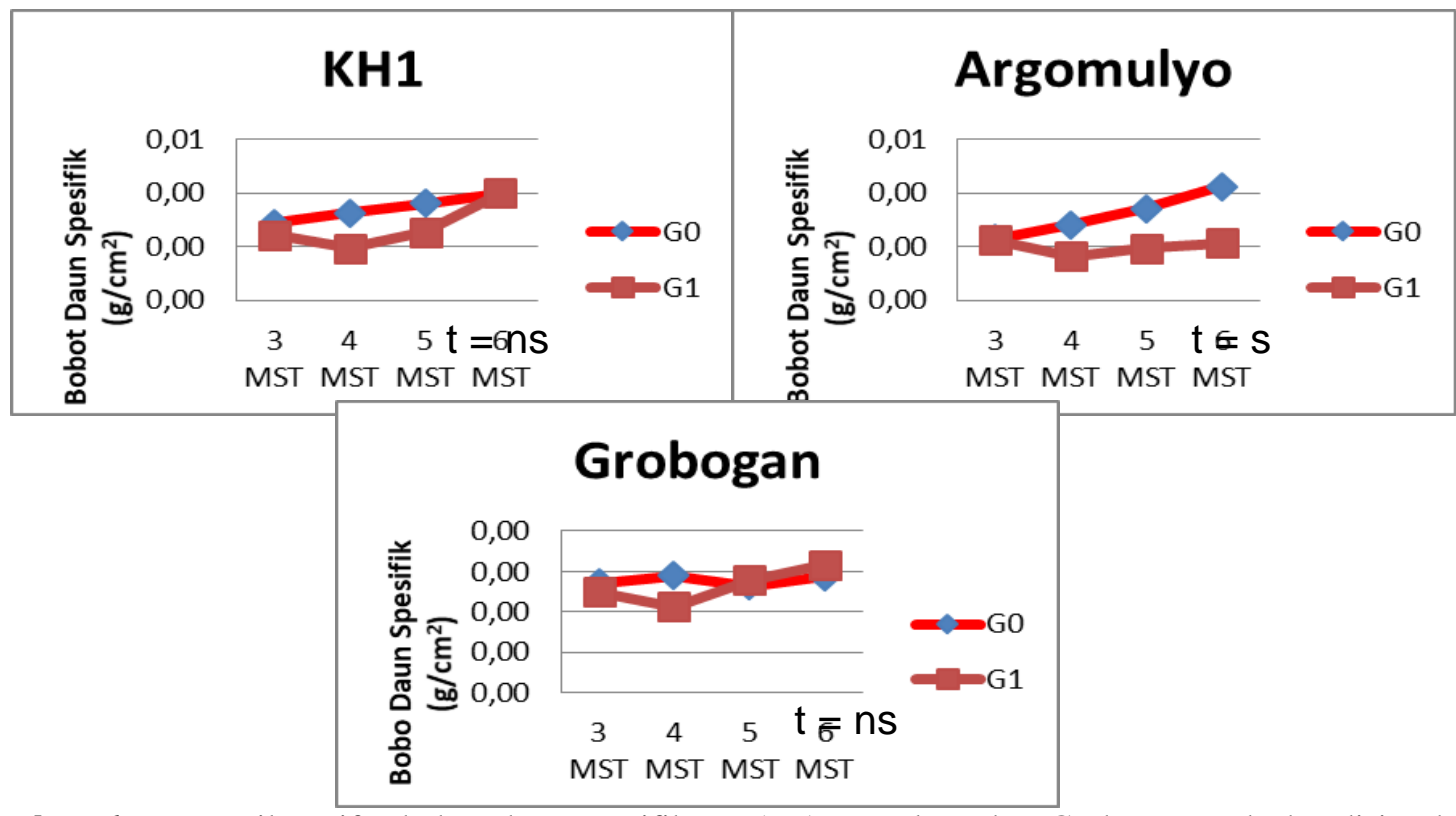

Gambar 6. Penampilan sifat bobot daun spesifik KH1, Argomulyo, dan Grobogan pada kondisi cekaman genangan

Pola pertumbuhan bobot daun spesifik (Gambar 6) menunjukkan perbedaan nyata pada genotipe Argomulyo dimana sejak umur 4 MST sampai 6 MST jauh lebih rendah pada kondisi genangan dibanding pada kondisi normal, sedangkan KH1 dan Grobogan terutama pada umur 6 MST hampir sama pada kondisi genangan dan normal.

Tabel 2. Hasil t test penampilan karakter rasio BB akar/tajuk tiga genotipe kedelai biji besar pada kondisi cekaman genangan yang diamati pada umur 6 MST 


\begin{tabular}{|c|c|c|c|c|}
\hline \multirow[t]{2}{*}{ Genotipe } & \multicolumn{2}{|c|}{ Cekaman Genangan } & Perbedaan & \multirow[t]{2}{*}{ t-test } \\
\hline & Normal (G0) & Genangan (G1) & $\begin{array}{l}\text { Genangan - } \\
\text { Normal (G1-G0) }\end{array}$ & \\
\hline \multicolumn{5}{|c|}{ Rasio Berat Basah akar/tajuk } \\
\hline KH1 & 0.0600 & 0.2200 & 016000 & $\mathrm{~S}$ \\
\hline Argomulyo & 0.0625 & 0.2375 & 0.17500 & SS \\
\hline Grobogan & 0.0675 & 0.3375 & 0.27000 & $\mathrm{~s}$ \\
\hline \multicolumn{5}{|c|}{ Rasio Berat Kering akar/tajuk } \\
\hline KH1 & 0.0525 & 0.1100 & 0.0575 & $\mathrm{~ns}$ \\
\hline Argomulyo & 0.0675 & 0.1475 & 0.0800 & $\mathrm{~s}$ \\
\hline Grobogan & 0.0600 & 0.1100 & 0.0500 & ns \\
\hline \multicolumn{5}{|l|}{ Berat Brangkasan } \\
\hline KH1 & 20.4575 & 48.5850 & 28.127 & $\mathrm{~ns}$ \\
\hline Argomulyo & 22.4900 & 48.5750 & 26.085 & $\mathrm{~ns}$ \\
\hline Grobogan & 14.2075 & 36.1700 & 21.9625 & ns \\
\hline
\end{tabular}

Keterangan: $\mathrm{s}=$ berbeda nyata $5 \%, \mathrm{ss}=$ sangat berbeda nyata $1 \%, \mathrm{~ns}=$ tidak berbeda nyata

Pada Tabel 2 tampak bahwa rasio berat kering akar/tajuk ketiga genotipe yang diuji lebih tinggi pada kondisi genangan dibanding kondisi normal, namun Argomulyo menunjukkan perbedaan lebih tinggi secara signifikan pada kondisi genangan dibanding kondisi normal. Hal ini menunjukkan bahwa genotipe Agromulyo secara nyata menunjukkan perbedaan rerata berat akar lebih tinggi dibanding rerata berat tajuk pada kondisi genangan. Diduga pada kondisi genangan, serapan unsur hara yang dikirim ke tajuk berkurang sementara energi lebih banyak disalurkan ke bagian akar untuk membentuk akar adventif. Menurut Pezeshki,et al. [12], Pada tanaman oak, penyerapan unsur hara lebih rendah pada kondisi stres genangan dibandingkan dengan kontrol, dan total biomassa juga menurun secara signifikan pada kondisi cekaman genangan. Ini menunjukkan bahwa serapan unsur tanaman dan alokasi biomassa dipengaruhi oleh kondisi cekaman genangan. Hal ini juga sejalan dengan yang dilaporkan oleh Fatimah dan Saputro [5] bahwa perlakuan genangan lebih tinggi rasio akarnya dibanding dengan tajuknya pada kedelai varietas Grobogan. Rohmah dan Saputro [13] juga melaporkan bahwa parameter akar adventif mengalami peningkatan seiring dengan peningkatan konsentrasi cekaman genangan. Sebagaimana juga yang dilaporkan Komariah et al. [14] bahwa tanaman kedelai yang tergenang mampu membentuk akar adventif. Hal ini terjadi karena tanaman memiliki daya adaptasi terhadap lingkungan perakaran yang kekurangan oksigen dengan cara membentuk akar lateral dan akar adventif. Pada saat tanaman dalam keadaan hipoksia (kekurangan $\mathrm{O}_{2}$ ), akar adventif akan terbentuk pada bagian atas akar mendekati permukaan tanah di mana tekanan oksigen tinggi. Akar adventif dapat mengurangi pengaruh buruk genangan dengan memperluas area perakaran ke udara, meningkatkan respirasi aerob, dan mengoksidasi rizosfer. Hasil penelitian ini juga sejalan dengan yang dilaporkan oleh Syah et al. [8] pada tanaman jagung bahwa berat kering akar dalam kondisi normal berpotensi digunakan untuk skrining awal. Genotipe adaptif pada cekaman genangan air yang dipilih berdasarkan berat kering akar adalah diprediksi menunjukkan hasil lebih tinggi 0.57 ton $\mathrm{ha}^{-1}$ daripada nilai rata-rata seluruh genotipe pada kondisi cekaman genangan air. Secara umum, Grobogan pada penelitian ini tidak menunjukkan penampilan sifat vegetatif yang lebih baik dibanding KH1 dan Argomulyo, 
meskipun Balitbangtan Kementerian Pertanian [15]. melaporkan bahwa Grobogan merupakan varietas toleran cekaman genangan air.

\section{KESIMPULAN}

Genangan dan genotipe berpengaruh nyata pada tinggi tanaman, diameter batang, jumlah dan luas daun trifoliat, berat kering akar dan tajuk, dan rasio berat akar/tajuk. Terdapat perbedaan penampilan karakter vegetatif tiga genotipe kedelai biji besar pada kondisi stres genangan terutama pada sifat tinggi tanaman, bobot daun spesifik, berat akar, dan rasio berat akar/tajuk. Pada kondisi stres genangan, KH1 menunjukkan tinggi tanaman, berat kering akar, dan berat kering tajuk yang paling tinggi. Argomulyo menunjukkan luas daun yang paling tinggi, sedangkan Grobogan justru tidak menunjukkan karakter dominan pada kondisi stres genangan.

\section{Ucapan Terima Kasih}

Ucapan terimakasih kami sampaikan kepada Bapak Rektor Uiversitas Mataram, Bapak Dekan Fakultas Pertanian Universitas Mataram, Bapak Kepala LPPM Universitas Mataram yang telah memfasilitasi pelaksanaan penelitian ini baik berupa dana, administrasi, dan fasilitas lain.

\section{DAFTAR PUSTAKA}

[1] Balai penelitian Tanaman Aneka Kacang dan Umbi, Badan Litbang Pertanian. 2012. Teknologi Produksi Kedelai Untuk Lahan Sawah, Lahan Kering dan Lahan Pasang Surut Tipe C dan D

[2] Nuryati, L., Waryanto, B., Noviati, \& Widaningsih, R. 2015. Outlook Komoditas Pertanian Tanaman Pangan Kedelai. Pusat Data dan Sistem Informasi Pertanian Kementerian Pertanian. Jakarta

[3] Hapsari, RT. \& Adie, MM. 2010. Peluang Perakitan dan Pengembangan Kedelai Toleran Genangan. Jurnal Litbang Pertanian, 29, 50-57

[4] Efendi, R. \& Suwarti. 2013. Antisipasi Perubahan Iklim dengan Perakitan Varietas Jagung Toleran Kekeringan dan Genangan. Seminar Nasional Inovasi Teknologi Pertanian.

[5] Fatimah, V.S. \& Saputro, T.B. 2016. Respon Karakter Fisiologis Kedelai (Glycine max L.) Verietas Grobogan terhadap Cekaman Genangan. Jurnal Sains Dan Seni ITS 5, 2337-3520

[6] McKevlin, M.R., Hook, D.D., \& McKee. W.H. 1995. Growth and nutrient use efficiency ofwater tupelo seedlings in flooded and well drained soil. Tree Physiol. 15, 753-758.

[7] Rakhman, R.Y. 2016. Respon Cekaman Genangan Periodik Pada Beberapa Varietas Nicotiana tabacum. Tugas Akhir - Sb141510 Jurusan Biologi Fakultas Matematika Dan Ilmu Pengetahuan Alam, Institut Teknologi Sepuluh Nopember Surabaya. 
[8] Suwarti, Iriani, N., \& Pabbage, M.S. 2013. Seleksi Plasma Nutfah Jagung terhadap Cekaman Genangan Air. Seminar Nasional Inovasi Teknologi Pertanian, 2013. 116132

[9] Syah, U.T., Suwarno, W.B., Azrai, M. 2019. Karakter Seleksi Fase Vegetatif untuk Adaptasi Cekaman Genangan Air pada Jagung. J. Agron. Indonesia, 47,134-140

[10] Susilawati, Suwignyo, R.A., Munandar, \& Hasmeda, M. 2012. Karakter Agronomi dan Fisiologi Varietas Cabai Merah pada Kondisi Cekaman Genangan. J. Agron. Indonesia 40, 196 - 203

[11] Van Toai, T.T., Hoa, T.T.C., Hue, N.T.N., Nguyen, H., Shannon, J.G. \& Bishop. B. 2007. Diversity in Tolerant of Soybean (G;ycine max L. Merr.) Germplasm to Soil Waterlogging. Paper Presented at International Annual Meetings. New Orleans, Louisiana 4-8 November 2007.

[12] Pezeshki, S.R., DeLaune, R.D., \& Anderson, P.H. 1999. Effect of Flooding on Elemental Uptake and Biomass Allocation in Seedlings of Three Bottomland Tree Species. Journal of Plant Nutrition, 22, 1481-1494

[13] Rohmah, E.A., \& Saputro, T.B. 2016. Analisis Pertumbuhan Tanaman Kedelai (Glycine $\max$ L.) Varietas Grobogan Pada Kondisi Cekaman Genangan. Jurnal Sains Dan Seni ITS 5, 2337-3520

[14] Komariah, A. A. Baihaki, R. Setiamihardja, dan S. Djakasutami. 2004. Hubungan antara aktivitas nitrat reduktase, kadar $\mathrm{N}$ total, dan karakter penting lainnya dengan toleransi tanaman kedelai terhadap genangan. Zuriat 15(2): 163-169.

[15] Balitbangtan Kementerian Pertanian, 2011. Pedoman Umum Adaptasi Perubahan Iklim Sektor Pertanian. Jakarta. $67 \mathrm{~h}$ 